\title{
Measurement of radioactive heat generation in rocks by means of gamma ray spectrometry
}

\author{
Vertical distribution of heat source in the island arc crust
}

\author{
By Makiko MukaI ${ }^{*)}$ Tohru Yamaguchi, ${ }^{* *)}$ Kazuhisa Komura, ${ }^{* * *)}$ Muneyoshi Furumoto, ${ }^{*)}$ \\ and Toshiyasu NAGAO ${ }^{* * * *,+\dagger)}$ \\ (Communicated by Seiya UyedA, M. J. A., Sept. 13, 1999)
}

\begin{abstract}
Terrestrial heat flow is the sum of the radioactive heat generated in the crust and the heat flow from the mantle. If we can evaluate the radioactive heat generation in the crust more precisely, we can better estimate the heat flow from the mantle and the thermal state in the earth crust. In this study, the authors measured the contents of radioactive elements in rocks of Kohistan volcanic arc, Pakistan and Ichinomegata, northeast Japan. We conclude that low density rocks $(\rho \leqq 2.9)$ systematically contain much more radioactive elements leading to high heat generation compared with high density rocks $(\rho \geqq 3.0)$. In the next step, the vertical distribution of radioactive heat generation in the crust was estimated, and the heat generation of the lower crust in the two areas was found to be much lower than previously considered. It means, if the surface heat flow is the same, the estimated temperature at $30 \mathrm{~km}$ depth is about $80^{\circ} \mathrm{C}$ higher than previous estimates. This temperature change may strongly affect the seismic activity at the depth.
\end{abstract}

Key words: Heat generation; heat flow; radioactive elements; lower crust.

Introduction. In the study of the thermal evolution of the earth, major candidate processes of energy discharge from the earth are terrestrial heat flow, volcanic activity, hot spring/geothermal activity and earthquakes. The major heat sources in the earth are the decay of radioactive elements, and the gravitational energy released at the time of earth's formation by accretion.

Terrestrial heat flow is the only directly measurable parameter to estimate the thermal state in the earth. The surface heat flow density consists of the so called mantle heat flow and the heat produced in the crust. Therefore, to estimate the mantle heat flow and the temperature structure in the crust more precisely, detailed information of the vertical distribution of radiogenic heat production rate is important.

\footnotetext{
*) Department of Earth Sciences, Faculty of Science, Kanazawa University, Kakuma, Kanazawa, Ishikawa 920-1192, Japan.

**) RIKEN International Frontier Program on Earthquake Research, c/o Earthquake Prediction Research Center, Tokai University, 3-20-1 Orido, Shimizu, Shizuoka 424-8610, Japan.

***) Low Level Radioactivity Laboratory, Kanazawa University, Wake, Tatsunokuchi, Nomi-gun, Ishikawa 923-1224, Japan.

****) Earthquake Prediction Research Center, Tokai University, 3-20-1 Orido, Shimizu, Shizuoka 424-8610, Japan.

†) Correspondence to: T. Nagao.
}

It is well known that radioactive elements; i.e., $\mathrm{U}$, $\mathrm{Th}, \mathrm{K}$ are contained mainly in felsic rocks. ${ }^{1)}$ This feature is explained by the "incompatible" nature of these elements. ${ }^{2}$ So far, almost all studies concerning the vertical distribution of heat generation have been made in stable continental regions, ${ }^{3)}$ and the study, in tectonically active regions like Japan, is very few. ${ }^{4)}$

In order to know the total amount of radioactive heat in the crust, we have to make direct measurements on all the crustal rocks. However, since it is very difficult to obtain the rock samples all the depths, attempts have also been made to infer the vertical distribution of the radioactive heat generation from other parameters. Birch et al. ${ }^{5)}$ demonstrated a linear relation between the surface heat flow and the content of radioactive elements of surface rocks. This linear relationship has been theoretically shown to be compatible with the model in which radioactive elements decreased exponentially with depth. ${ }^{6)}$

Separate estimations of heat production structure in the crust have also been made by using the empirical relations between the contents of radiogenic heat production and density, and seismic velocity. ${ }^{7-9)}$ In the latter case, Rybach and Buntebarth ${ }^{9)}$ formulated the following two linear equations: 
(a)

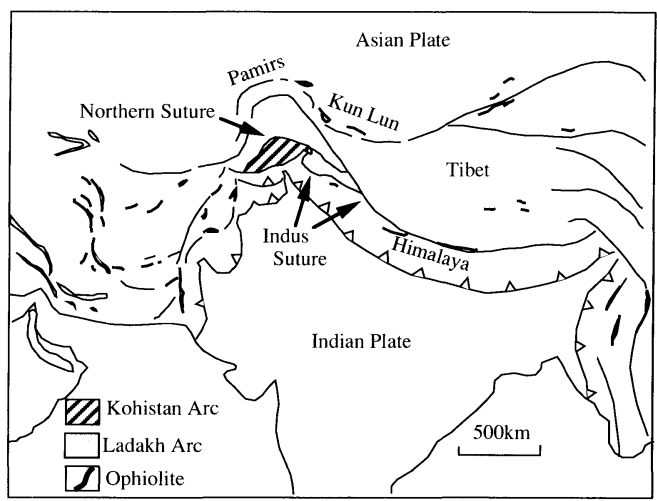

(b)

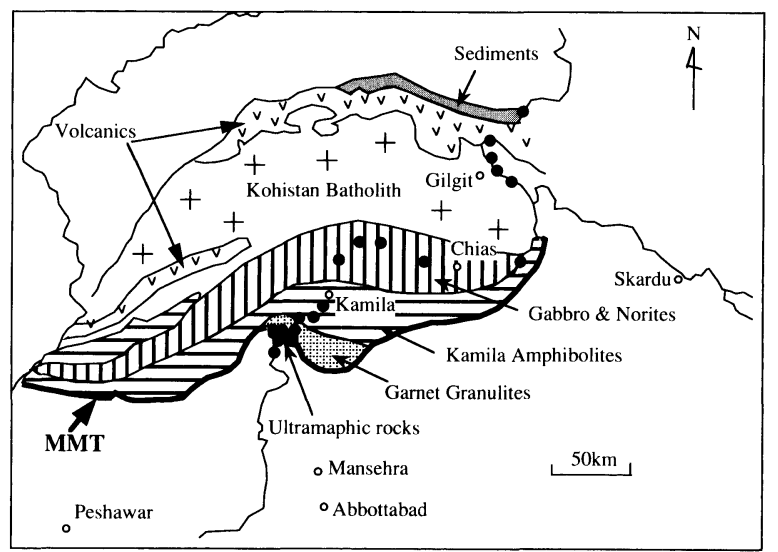

Fig. 1. Fig. 1a shows the location of the Kohistan Arc. Kohistan area belongs to the northern part of Pakistan, which lies between Eurasian and Indian continents. Fig. 1b shows the geological map and the sampling sites with solid circles.

$\ln \mathrm{A}=12.6-2.17 \mathrm{Vp}$ for Precambrian crust, and $\ln \mathrm{A}=13.7-2.17 \mathrm{Vp}$ for Phanerozoic crust,

where $\mathrm{A}\left(10^{-6} \mathrm{~W} / \mathrm{m}^{3}\right)$ is the heat production, $\mathrm{Vp}(\mathrm{km} / \mathrm{s})$ is the seismic P-wave velocity.

Furukawa and Uyeda ${ }^{4)}$ measured the radiogenic heat production of the upper crustal granitic rocks of Hidaka District, Hokkaido, Japan. Where the crustal section is extensively exposed as a result of tectonic movement and erosion associated with the collision of the western and eastern Hokkaido blocks. ${ }^{10)}$ They concluded that the obtained rate of heat generation and its decrease with increasing depth were similar to those estimated for stable continental areas. However, due to the lack of lower crustal samples, they assumed constant heat generation $\left(1 \times 10^{-6} \mathrm{~W} / \mathrm{m}^{3}\right)$ for the lower crust in their calculation. To the best of the authors' knowledge, no measurement has been made for the lower crustal rocks in tectonically active regions such as island arcs. For the possible mantle rocks, some reports are

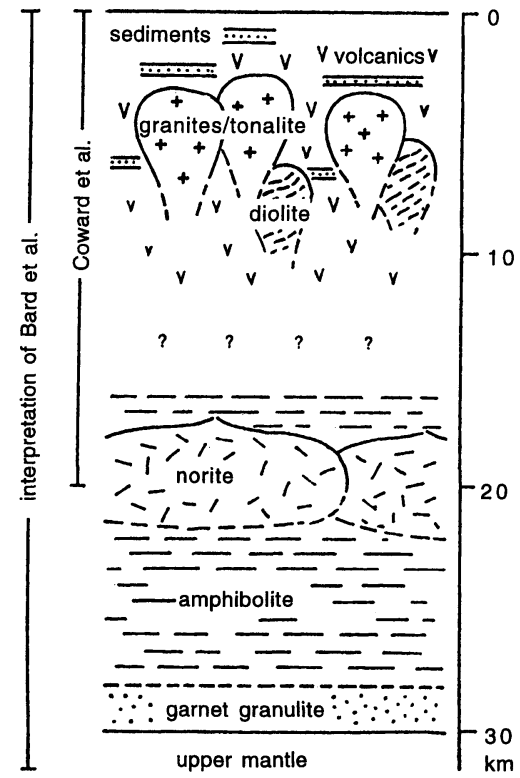

Fig. 2. Schematic geologic column of the Kohistan Arc.

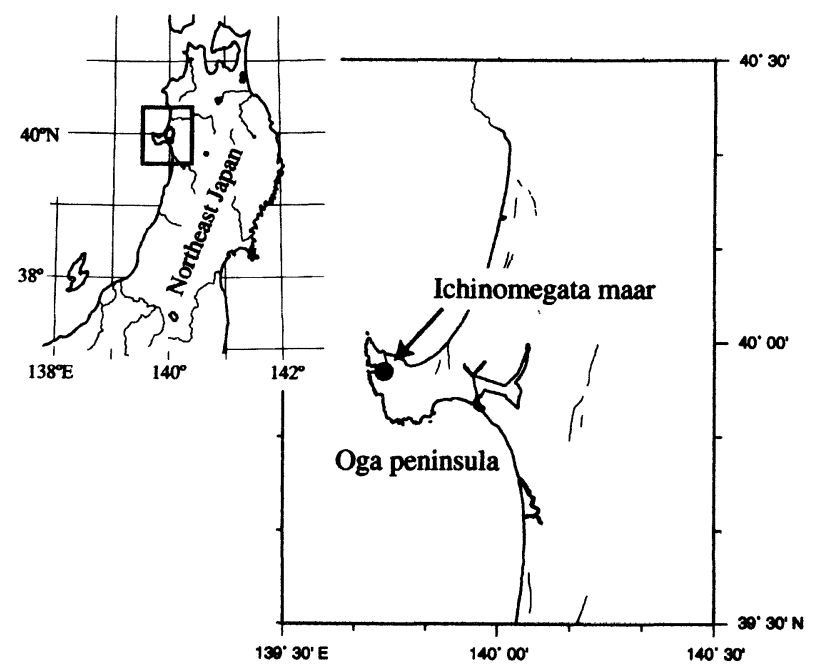

Fig. 3. The location of the Ichinomegata maar, Oga peninsula, northeast Japan.

found. ${ }^{11)}$ Wakita et al., ${ }^{12)}$ also reported the results from lherzolite of Ichinomegata maar in northeast Japan.

The main objectives of this paper is to provide some useful information of the vertical distribution of radiogenic elements in the island arc crust. We measured the contents of radioactive elements of the rock samples of the Kohistan Arc, Pakistan, and Ichinomegata maar, Oga peninsula, northeast Japan, by gamma ray spectrometry analysis.

Samples. Kohistan arc is located in the northern part of Pakistan, where Indian subcontinent has been in collision with Eurasia (Fig. 1a). It is considered that 
Table I. U, Th, K contents, calculated heat production, density and lithology of Kohistan samples

\begin{tabular}{|c|c|c|c|c|c|c|c|c|c|c|c|c|}
\hline No. & Sample name & $\begin{array}{c}\mathrm{U} \\
(\mathrm{ppm})\end{array}$ & $\begin{array}{l}\text { Error } \\
(\mathrm{ppm})\end{array}$ & $\begin{array}{c}\text { Th } \\
(\mathrm{ppm})\end{array}$ & $\begin{array}{l}\text { Error } \\
(\mathrm{ppm})\end{array}$ & $\begin{array}{c}\mathrm{K} \\
(\%)\end{array}$ & $\begin{array}{c}\text { Error } \\
(\%)\end{array}$ & $\frac{\mathrm{A}}{\left(\mu \mathrm{W} / \mathrm{m}^{3}\right)}$ & $\begin{array}{c}\text { Error } \\
\left(\mu \mathrm{W} / \mathrm{m}^{3}\right)\end{array}$ & $\begin{array}{c}\text { Density } \\
\left(\mathrm{g} / \mathrm{m}^{3}\right)\end{array}$ & $\begin{array}{l}\text { Error } \\
\left(\mathrm{g} / \mathrm{m}^{3}\right)\end{array}$ & Lithology \\
\hline 1 & Nilt $10 \mathrm{kmN}$ & 2.069 & 0.095 & 17.800 & 0.300 & 2.055 & 0.041 & 2.03 & 0.05 & 2.81 & 0.06 & Pelitic schist \\
\hline 2 & Gligit $11 \mathrm{kmS}$ & 1.480 & 0.041 & 5.800 & 0.200 & 1.464 & 0.036 & 0.93 & 0.02 & 2.74 & 0.01 & Pelitic schist \\
\hline 3 & Hunza $70 \mathrm{kmS}$ & 0.161 & 0.011 & 0.299 & 0.030 & $0 . .516$ & 0.016 & 0.11 & 0.00 & 2.70 & 0.01 & Meta-Granite \\
\hline 4 & Jaglot 33kmS & 8.090 & 0.150 & 5.710 & 0.200 & 3.003 & 0.055 & 2.73 & 0.06 & 2.67 & 0.04 & Meta-Granite \\
\hline 5 & Gligit $0 \mathrm{~km}$ & 0.797 & 0.038 & 8.240 & 0.190 & 2.228 & 0.054 & 0.98 & 0.02 & 2.70 & 0.02 & Granite \\
\hline 6 & Dasu $14 \mathrm{kmS}$ & 0.340 & 0.080 & 1.300 & 0.120 & 0.190 & 0.020 & 0.21 & 0.02 & 2.89 & 0.05 & Micro-Diorite \\
\hline 7 & Chilas $50 \mathrm{kmS}$ & 0.038 & 0.008 & 0.085 & 0.008 & 0.107 & 0.006 & 0.03 & 0.00 & 2.88 & 0.03 & Diorite \\
\hline 8 & Dasu $19 \mathrm{kmS}$ & 0.080 & 0.008 & 0.267 & 0.013 & 0.178 & 0.000 & 0.06 & 0.00 & 2.85 & 0.01 & Diorite \\
\hline 9 & Sazin 0km & 0.138 & 0.015 & 0.327 & 0.038 & 0.209 & 0.008 & 0.08 & 0.01 & 2.90 & 0.01 & Meta-Diorite \\
\hline 10 & Hunza $55 \mathrm{kmS}$ & 0.090 & 0.019 & 0.145 & 0.025 & 0.178 & 0.005 & 0.05 & 0.01 & 2.95 & 0.04 & Amphibolite \\
\hline 11 & Chilas 25kmS & 0.179 & 0.011 & 0.493 & 0.042 & 0.363 & 0.008 & 0.12 & 0.00 & 2.93 & 0.01 & Norite \\
\hline 12 & Paton $2 \mathrm{kmS}$ & 0.037 & 0.007 & 0.062 & 0.042 & 0.123 & 0.006 & 0.03 & 0.00 & 3.02 & 0.01 & Norite \\
\hline 13 & Sazin $30 \mathrm{kmS}$ & 0.008 & 0.002 & 0.024 & 0.003 & 0.087 & 0.000 & 0.01 & 0.00 & 3.14 & 0.01 & Gabbro \\
\hline 14 & Paton $1 \mathrm{kmN}$ & 0.060 & 0.004 & 0.123 & 0.008 & 0.268 & 0.005 & 0.05 & 0.00 & 2.94 & 0.01 & Epidote-Amphibolite \\
\hline 15 & Paton $1 \mathrm{kmS}$ & 0.022 & 0.003 & 0.033 & 0.006 & 0.183 & 0.004 & 0.03 & 0.00 & 3.47 & 0.10 & Garnet granulite \\
\hline 16 & Paton $7.4 \mathrm{kmS}$ & 0.021 & 0.002 & 0.095 & 0.004 & 0.037 & 0.000 & 0.02 & 0.00 & 3.31 & 0.11 & Garnet granulite \\
\hline 17 & jijal & 0.006 & 0.001 & 0.020 & 0.003 & 0.004 & 0.000 & 0.00 & 0.00 & 3.23 & 0.08 & Clinoyroxene \\
\hline
\end{tabular}

Table II. U, Th, K contents, calculated heat production, density and lithology of Ichinomegata samples

\begin{tabular}{|c|c|c|c|c|c|c|c|c|c|c|c|c|}
\hline No. & Sample name & $\begin{array}{c}\mathrm{U} \\
(\mathrm{ppm})\end{array}$ & $\begin{array}{l}\text { Error } \\
\text { (ppm) }\end{array}$ & $\begin{array}{c}\text { Th } \\
(\mathrm{ppm})\end{array}$ & $\begin{array}{l}\text { Error } \\
(\mathrm{ppm})\end{array}$ & $\begin{array}{c}\mathrm{K} \\
(\%)\end{array}$ & $\begin{array}{c}\text { Error } \\
(\%)\end{array}$ & $\begin{array}{c}\text { A } \\
\left(\mu \mathrm{W} / \mathrm{m}^{3}\right)\end{array}$ & $\begin{array}{c}\text { Error } \\
\left(\mu \mathrm{W} / \mathrm{m}^{3}\right)\end{array}$ & $\begin{array}{c}\text { Density } \\
\left(\mathrm{g} / \mathrm{m}^{3}\right)\end{array}$ & $\begin{array}{l}\text { Error } \\
\left(\mathrm{g} / \mathrm{m}^{3}\right)\end{array}$ & Lithology \\
\hline 1 & Ich-10004 & 0.680 & 0.040 & 0.720 & 0.090 & 1.060 & 0.030 & 0.34 & 0.02 & 2.86 & 0.07 & Meta-Basalt \\
\hline 2 & Ich-10003 & 0.286 & 0.024 & 0.765 & 0.068 & 0.151 & 0.010 & 0.15 & 0.01 & 2.93 & 0.02 & Hornblende-gabbro \\
\hline 3 & $\mathrm{I}-464$ & 0.130 & 0.030 & 0.320 & 0.060 & 0.180 & 0.010 & 0.08 & 0.01 & 2.91 & 0.04 & Hornblende-gabbro \\
\hline 4 & $\mathrm{I}-1077$ & 0.340 & 0.007 & 1.652 & 0.017 & 0.328 & 0.008 & 0.25 & 0.05 & 2.87 & 0.6 & Amphibolite \\
\hline 5 & $\mathrm{I}-402$ & 0.081 & 0.014 & 0.113 & 0.042 & 0.242 & 0.012 & 0.06 & 0.01 & 2.91 & 0.04 & Amphibolite \\
\hline 6 & $\mathrm{I}-1043$ & 0.074 & 0.011 & 0.056 & 0.034 & 0.148 & 0.012 & 0.04 & 0.00 & 3.12 & 0.04 & Hornblende-gabbro \\
\hline 7 & $\mathrm{I}-661$ & 0.057 & 0.011 & 0.090 & 0.008 & 0.304 & 0.011 & 0.06 & 0.00 & 3.07 & 0.03 & Hornblende-gabbro \\
\hline 8 & I-1078 & 0.059 & 0.007 & 0.081 & 0.017 & 0.078 & 0.005 & 0.03 & 0.00 & 3.25 & 0.04 & Pyroxene-gabbro \\
\hline 9 & Ich-10002 & 0.098 & 0.007 & 0.156 & 0.013 & 0.061 & 0.003 & 0.05 & 0.00 & 3.15 & 0.08 & Pyroxene-gabbro \\
\hline 10 & Ich-10000 & 0.123 & 0.011 & 0.068 & 0.076 & 0.011 & 0.002 & 0.04 & 0.01 & 3.12 & 0.07 & Websterite \\
\hline 11 & Ich-10005 & 0.142 & 0.012 & 0.095 & 0.017 & 0.018 & 0.002 & 0.05 & 0.00 & 3.24 & 0.05 & Websterite \\
\hline 12 & $\mathrm{I}-1071$ & 0.068 & 0.007 & 0.143 & 0.017 & 0.219 & 0.008 & 0.05 & 0.00 & 2.93 & 0.05 & Websterite \\
\hline 13 & I-665 & 0.051 & 0.005 & 0.118 & 0.008 & 0.020 & 0.002 & 0.03 & 0.00 & 3.28 & 0.03 & Olivine-Websterite \\
\hline 14 & Ich-10001 & 0.110 & 0.040 & 0.110 & 0.060 & 0.011 & 0.003 & 0.05 & 0.01 & 3.37 & 0.07 & Lherzolite \\
\hline 15 & I-637 & 0.029 & 0.004 & 0.092 & 0.013 & 0.014 & 0.002 & 0.02 & 0.00 & 3.34 & 0.09 & Lherzolite \\
\hline
\end{tabular}

Kohistan arc (from southern MMT (Main Mantle Thrust) to Northern Suture) was formed between the late Jurassic and Cretaceous times. Almost complete crustal cross section of this arc is believed to be exposed; progressively deeper structure is outcropped toward south. ${ }^{13)}$ Fig. 1b show the geological map. Fig. 2 shows a schematic cross section, and detailed geological setting is described in Coward et al., ${ }^{14)}$ and Ohta. ${ }^{15)}$ According to the isotopic dating and palaeomagnetic studies, collision to the Eurasia continent at Northern Suture occurred $75 \mathrm{Ma}$, and collision at MMT occurred 40-50 Ma. ${ }^{13), 16), 17)}$ The seismic activity, considered to be of the subduction origin, is still observed at present. ${ }^{14)}$ Fig. $1 \mathrm{~b}$ also shows the sampling sites.

Ichinomegata, Ninomegata and San-nomegata, in Oga peninsula, Akita prefecture are maars which erupt- ed about 10,000 years ago according to $\mathrm{C}_{14}$ dating $9,040 \pm 400$ years B.P. ${ }^{18)}$ Around Ichinomegata maar, zenoliths of various mantle and lower crustal rocks are exposed. Geophysical studies show that the depth of Moho discontinuity around this region is about 25 km. ${ }^{19)}$ Fig. 3 shows the location of the Ichinomegata region.

Data analysis. The total amount of radiogenic heat in the crust is estimated from the content of uranium (U), thorium (Th) and potassium (K). Since the parent nuclides of the uranium and thorium series emit very low level of gamma-rays, we estimated their contents by gamma ray spectrometry of their daughter nuclides. The high advantages of this method, if germanium semiconductor sensor is used, is high resolution of energy distribution, without performing chemical separation and 


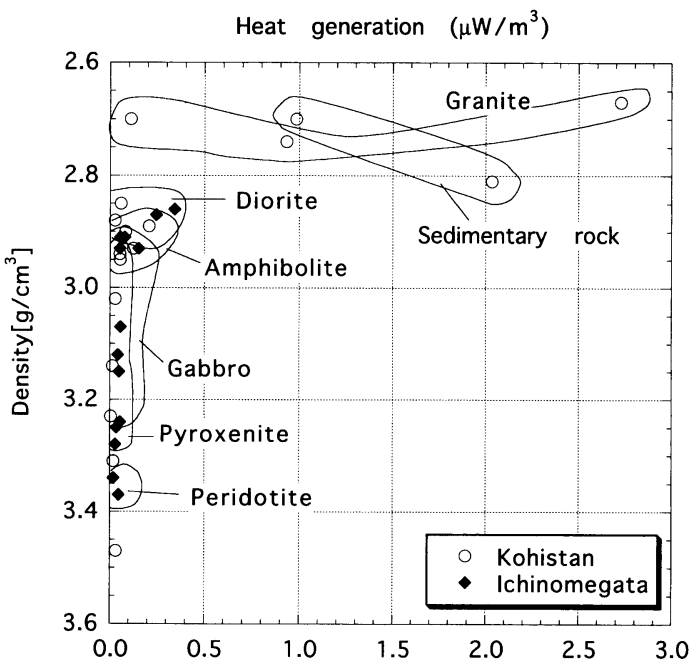

Fig. 4. Correlation between density and radiogenic heat production of Kohistan and Ichinomegata samples. General rock types are also indicated.

the capability of simultaneous measurement of many nuclides.

We measured 17 samples from the Kohistan region, and 15 samples from the Ichinomegata maar region. We used the following peaks to determine the contents; ${ }^{214} \mathrm{~Pb}(295,352 \mathrm{keV}),{ }^{214} \mathrm{Bi}(609 \mathrm{keV})$ for uranium, ${ }^{212} \mathrm{~Pb}(239 \mathrm{keV}),{ }^{228} \mathrm{Ac}(338,911 \mathrm{keV}),{ }^{208} \mathrm{Tl}(583$, $2,614 \mathrm{keV})$ for thorium, and ${ }^{40} \mathrm{~K}(1,460 \mathrm{keV})$ for potassium, respectively. The radiogenic heat production values were calculated as follows. ${ }^{20}$

$$
\mathrm{A}=\rho\left(9.52 \mathrm{C}_{\mathrm{U}}+2.56 \mathrm{C}_{\mathrm{Th}}+3.48 \mathrm{C}_{\mathrm{K}}\right) \times 10^{-5}
$$

where $\mathrm{A}$ is the heat production $\left(\times 10^{-6} \mathrm{~W} / \mathrm{m}^{3}\right), \mathrm{C}_{\mathrm{U}}$ and $\mathrm{C}_{\mathrm{Th}}$ are the $\mathrm{U}$ and Th concentration (ppm), respectively, $\mathrm{C}_{\mathrm{K}}$ is the $\mathrm{K}$ concentration (\%), and $\rho$ the density $\left(\mathrm{kg} / \mathrm{m}^{3}\right)$.

Result and discussion. Tables I and II show the $\mathrm{U}$, Th, K contents, calculated radiogenic heat production and density for the rocks from the Kohistan and Ichinomegata regions, respectively. The results are also shown in Fig. 4. As seen in the tables and Fig. 4, U, Th, K contents and the amount of heat production are large for low density samples. The amount of heat production, in fact, shows an abrupt drop when the density exceeds about $2.8 \mathrm{~g} / \mathrm{cm}^{3}$.

Fig. 4 also shows the relationship between heat generation and rock types. Granite and sedimentary rocks show higher values and gabbros, pyroxenites and peridotites show lower values. It is clear that the radionuclides are concentrated in lighter rocks that constitute the upper crust. The results seem to be quite reasonable from the geochemical point of view, ${ }^{2)}$ since $\mathrm{U}$ and Th are known to be LIL (Large Ion Lithophil) ele-
Previous studies

$$
0 \mathrm{~km}
$$

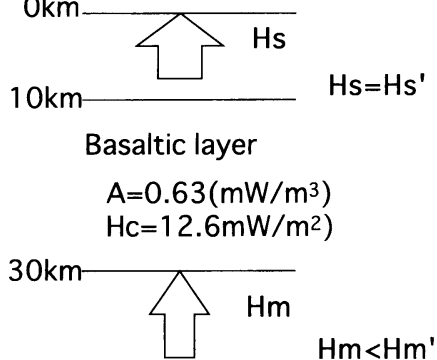

This study

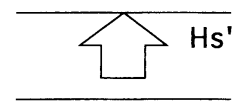

$\mathrm{A}^{\prime}=0.08\left(\mathrm{~mW} / \mathrm{m}^{3}\right)$

$\left.H c^{\prime}=1.6 \mathrm{~mW} / \mathrm{m}^{2}\right)$

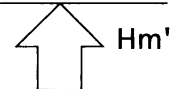

Fig. 5. The effect of heat generation in the lower crust. If the surface heat flow is the same, our model suggests that heat flow from the mantle is higher by order of $10 \mathrm{~mW} / \mathrm{m}^{2}$ than the previous studies. ${ }^{4)}$

ments, and $\mathrm{K}$ is a volatile element. All these elements are classified as 'incompatible elements' which can not be easily incorporated into crystal phase during the crystallization differentiation process. In addition, $\mathrm{U}$ is easy to move under the influence of meteoric and underground water movements, and Th tends to move under the influence of metamorphic process.

Generally, our results are in agreement with previous studies. However, there is some difference. In previous studies, due to lack of data, it has been customary to model the lower crust by basaltic rocks. In this study, we considered the effect of radiogenic heat production of the lower crust by assuming two models as shown in Fig. 5 ; the left and right figures show a conventional model and the present model. In our model, the average value of heat generation in the lower crust is taken to be 0.08 $\times 10^{-6} \mathrm{~W} / \mathrm{m}^{3}$, which is $1 / 8$ of conventional studies. ${ }^{1)}$ If we adopt the above small value, it results in larger mantle heat flow for the same surface heat flow. If we assume the thermal conductivity of the lower crust as 3.0 $\mathrm{W} / \mathrm{mK}$, the temperature at $30 \mathrm{~km}$ depth becomes 80 100 deg. Centigrade higher in our model (Fig. 6). The temperature of $80 \sim 100 \mathrm{deg}$. C at $30 \mathrm{~km}$ depth may strongly affect the capability of earthquakes generation which is supposed to be controlled by temperature sensitive brittle-ductile transition at the depth.

We can examine the relationship between density and $\mathrm{P}$ wave velocity of the Kohistan rocks, using the measurements by Chroston and Simmons. ${ }^{21)}$ For the Ichinomegata samples, we apply the general correlation between density and Vp compiled by Ludwig et al. ${ }^{22)}$ Fig. 7 shows the relationship between $\mathrm{P}$ wave velocity and heat production in the Kohistan and Ichinomegata samples. Indicated two lines are empirical relations obtained by Rybach and Buntebarth ${ }^{9)}$ as mentioned 


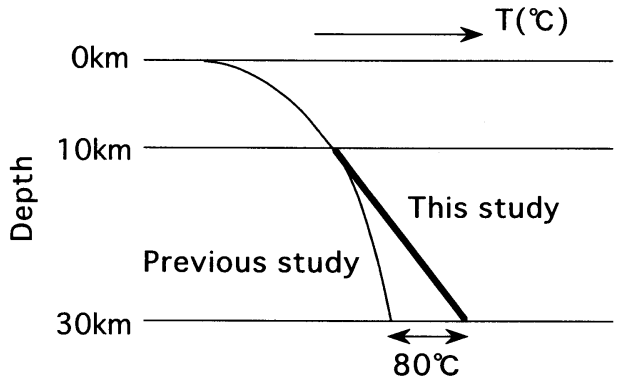

Fig. 6. The difference of the heat generation structure in the lower crust results in changes of about $80^{\circ} \mathrm{C}$ in the temperature at 30 $\mathrm{km}$ depth. This results can be of considerable importance for the estimate of the thickness of seismogenic layer.

before for Precambrian and Phanerozoic samples. At this stage, it is not clear if our data on relatively young (after Mesozoic era) island arc rocks are systematically different from stable continental data.

Conclusion. In this paper, we present the radiogenic heat production structure of the island arc crust, on the basis of some new measurements of radionuclide concentrations of island arc rocks. The new heat production structure consists of an upper crust with very large heat production values, and a lower crust with very low values. We also present very preliminary results on the relationship between heat generation and $\mathrm{P}$ wave velocity. For the next step, we will try to better estimate the heat generation structures in various parts of the world, especially for island arc regions, where the measurements on the accretionaly prism rocks may play an important role.

Acknowledgments. The authors thank Dr. Toshiaki Matsuda and Mr. Hirofumi Ohta for providing Kohistan samples and giving us useful comments. The authors' thanks are also extended to Dr. Shoji Arai for providing Ichinomegata samples and their thin sections. Dr. Seiya Uyeda, M.J.A., gave us a lot of useful comments and remarks.

\section{References}

1) Cermak, V., and Rybach, L. (1982) In Physical properties of Rocks (ed. Angenheister, G.). Springer Verlag, Berlin, Heidelberg and New York V1b, 305-481.

2) Jaupart, C., Sclater, J. G., and Simmons, G. (1981) Earth Planet. Sci. Lett. 52, 328-344.

3) Swanberg, C. A. (1972) J. Geophys. Res. 77, 2508-2513.

4) Furukawa, Y., and Uyeda, S. (1989) Tectonophysics 164, 175187.

5) Birch, F., Roy, R. F., and Decker, E. R. (1968) In Studies of Appalachian Geology (eds. E-an Zen, White, W. S.,

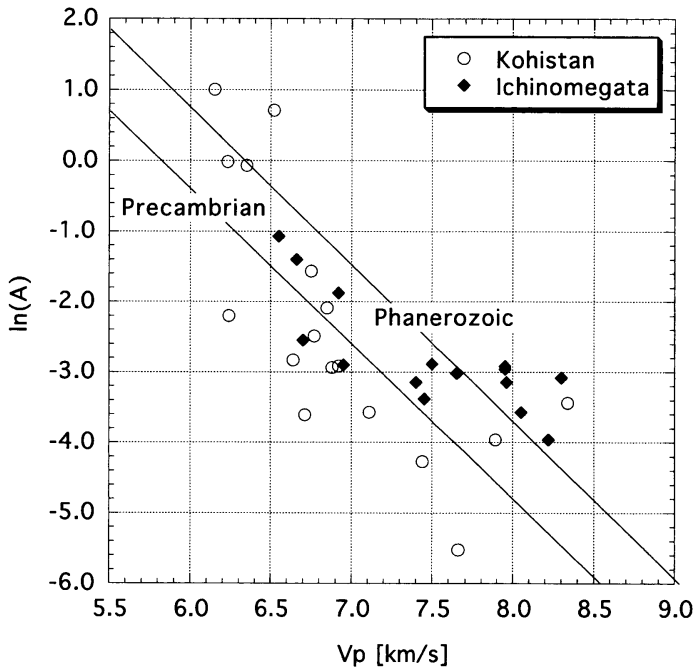

Fig. 7. Correlation between logarithm of heat generation and $\mathrm{Vp}$ of the rock samples. The two lines are for rocks from stable continental areas. ${ }^{9)}$

Haddley, J. B., and Thompson, J. B., Jr.). John Willey \& Sons, New York, pp.437-451.

6) Lachenbruch, A. H. (1970) J. Geophys. Res. 75, 3291-3300.

7) Rybach, L. (1976) Pageoph. 114, 309-317.

8) Rybach, L., and Buntebarth, G. (1982) Earth Planet. Sci. Lett. 57, 367-376.

9) Rybach, L., and Buntebarth, G. (1984) Tectonophysics $\mathbf{1 0 3 ,}$ 335-344.

10) Komatsu, M. (1985) Mem. Geol. Soc. Jpn. 25, 137-155.

11) Wakita, H., Nagasawa, H., Uyeda, S., and Kuno, H. (1967) Geochem. J. 1, 183-198.

12) Wakita, H., Nagasawa, H., Uyeda, S., and Kuno, H. (1967) Earth Planet. Sci. Lett. 2, 377-381.

13) Coward, M. P., Windley, B. F., Broughton, R. D., Luff, I. W., Petterson, C. J., Rex, D. C., and Asif Khan, M. (1986) In Collision Tectonics (eds. Coward, M. P., and Ries, A. C.). Geological Society Special Publication 19, 203-219.

14) Coward, M. P., Jan, M. Q., Rex, D., Tarney, J., Thirlwall, M., and Windley, B. F. (1982) J. Geophys. Res. 139, 299-308.

15) Ohta, H. (1991) Master thesis, Univ. of Shizuoka, Japan, pp. $1-85$

16) Bard, J. P. (1983) Earth Planet. Sci. Lett. 65, 133-144.

17) Petterson, M. J., and Windley, B. F. (1985) Earth Planet. Sci. Lett. 74, 45-57.

18) Katsui, Y., Yamamoto, M., Nemoto, S., and Niida, K. (1979) Jour. Fac. Sci., Hokkaido Univ., ser. 4 19, 157-168.

19) Yoshii, T. (1972) J. Phys. Earth 20, 271-285.

20) Kukkonen, I. T. (1989) Tectonophysics 164, 219-230.

21) Chroston, P. N., and Simmons, G. (1989) J. Geol. Soc., London 146, 971-979.

22) Ludwig, W. J., Nafe, J. E., and Drake, C., L. (1970) In the Sea. 4, part 1, Wiley-Interscience, p. 74. 